UNIVERSITÀ CATTOLICA DEL SACRO CUORE

Dipartimento di Economia e Finanza

\author{
Working Paper Series
}

Corruption and Legislature Size:

Evidence from Brazil

Diogo Britto, Stefano Fiorin

Working Paper n. 54

December 2016

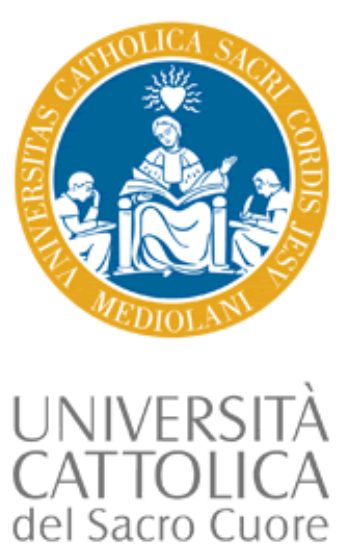




\title{
Corruption and Legislature Size: Evidence from Brazil
}

\author{
Diogo Britto \\ Università Cattolica del Sacro Cuore
}

Stefano Fiorin

UCLA Anderson

Working Paper n. 54

December 2016

\author{
Dipartimento di Economia e Finanza \\ Università Cattolica del Sacro Cuore \\ Largo Gemelli 1 - 20123 Milano - Italy \\ tel: +39.02.7234.2976 - fax: +39.02.7234.2781 \\ e-mail: dip.economiaefinanza@unicatt.it
}

The Working Paper Series promotes the circulation of research results produced by the members and affiliates of the Dipartimento di Economia e Finanza, with the aim of encouraging their dissemination and discussion. Results may be in a preliminary or advanced stage. The Dipartimento di Economia e Finanza is part of the Dipartimenti e Istituti di Scienze Economiche (DISCE) of the Università Cattolica del Sacro Cuore. 


\title{
Corruption and Legislature Size: Evidence from Brazil*
}

\author{
Diogo G. C. Britto ${ }^{\dagger}$ \\ Stefano Fiorin ${ }^{\ddagger}$
}

\begin{abstract}
This paper studies the role of council size on government corruption in Brazil. We leverage on the discontinuous relationship between the population size of municipalities and council size dictated by the law to implement a regression discontinuity design. We document a substantial positive causal effect of the number of city councilors on the incidence of corruption detected during federal audits. Results also show that having an extra councilor does not affect the size of the public budget, but influences its composition. It increases expenditures related to public housing and recreation, which we interpret as items related to clientelistic policies. Finally, we find a negative relationship between council size and its productivity: namely, the numbers of legislative bills proposed by councilor and approved are both lower in municipalities with larger councils.
\end{abstract}

Keywords: Corruption, Council Size, Regression Discontinuity

JEL Classification: D72, D73, H72

*We thank Massimo Bordignon, Christian Dippel, Ricardo Perez-Truglia, Paolo Roberti and numerous seminar participants at DSE Bologna and UCLA Anderson. We also thank Fernanda Brollo, Tommaso Nannicini, Roberto Perotti and Guido Tabellini for making their dataset on Brazilian corruption audits available.

${ }^{\dagger}$ Catholic University of Milan, diogo.britto@unicatt.it.

$\ddagger$ UCLA Anderson, stefanofiorin@ucla.edu. 


\section{Introduction}

There is a widespread consensus that corruption is high in developing countries (Olken and Pande, 2012). Audit reports from central government auditors in Brazil found that $79 \%$ of audited municipalities had at least one incidence of corruption, and that on average $8 \%$ of the resources audited were diverted through overinvoicing, illegal procurements, or direct diversion for private gains (Ferraz and Finan, 2011). Corruption has important adverse consequences on the citizens of those countries: for example, Brazilian students score less on standardized tests, and have significantly higher dropout and failure rates when municipal funds destined to education are diverted away from computer labs, teaching supplies, and teacher training (Ferraz et al., 2012).

A country can rely on its judiciary system to detect and punish corruption from its elected politicians after it happens, and on its citizens not to re-elect exposed corrupt politicians (Ferraz and Finan, 2008). While the threat of judiciary or electoral punishments may play a substantial role in corruption deterrence (Barro, 1973; Ferejohn, 1986; Barnett et al., 1993), it is generally a function of the legislative power to prevent corruption by overseeing and imposing limits to the executive power, and to denounce episodes of corruption as they happen. In Brazilian municipalities, city councilors, on top of submitting bills and public works requests, are indeed also in charge of monitoring the use of public resources by the mayor and of taking action in case of misconduct. For example, Globo, the largest media conglomerate in Brazil, reports the case of councilors from the municipality of Caracai who denounced the mayor for over-invoicing in 2015. Another episode reported by the same newspaper is the case of Teresopólis where the city councilors decided to suspend the mayor in 2011 due to corruption charges. ${ }^{1}$ Nevertheless, legislators are themselves self-interested political actors who can both divert public funds for

\footnotetext{
${ }^{1}$ See http://g1.globo.com/rr/roraima/noticia/2015/05/ vereadores-denunciam-prefeito-de-caracarai-sul-de-rr-por-improbidade. html and http://g1.globo.com/rio-de-janeiro/noticia/2011/08/ vereadores-decidem-afastar-do-cargo-prefeito-de-teresopolis-no-rj.html
} 
their own private gain and/or allow the mayor to do so: either because fighting corruption is not the main priority in their political agenda or in exchange for political favors. For instance, in November 2008 the Gazeta do Povo, a state newspapers from Parana, reports arrest the of two councilors from the municipality of Sandovalina for extorting money from the mayor in exchange of support for the approval of a budget increase. A different example reported by Globo is the case of a councilor's spouse from the municipality of Paulista who is found to receive benefits from Bolsa Famlia, a federal means-tested cash transfer program in Brazil administered at the municipality level. ${ }^{2}$ It remains an empirical question whether increasing the number of city councilors reduce or increase corruption at the municipal level.

In this paper, we evaluate for the first time the overall effect of larger city council size on corruption. There are two main challenges related to the study of the effect of legislative organization on corruption: measurement and identification. Instead of relying on indices of perceived corruption (Olken, 2009), we use an objective measure of corruption based on anti-corruption audits of Brazilian municipalities (the same measure used in Brollo et al. (2013)). Nonetheless, even with a good measure of corruption, identifying the causal impact of legislative organization is challenging in situations where the choice of council size is endogenous. For example, a positive correlation between council size and corruption could arise if corrupt mayors favor larger councils with the purpose of offering positions to their political affiliates. In a spirit similar to Egger and Koethenbuerger (2010) and Pettersson-Lidbom (2012), we overcome this challenge by exploiting a source of exogenous variation in council size: in Brazilian municipalities council size is a deterministic and discontinuous function of population size. Using a sharp regression discontinuity design, we estimate that increasing council size by one extra councilor causally increases the probability of a municipality being involved in at least

\footnotetext{
${ }^{2}$ See http://www.gazetadopovo.com.br/vida-e-cidadania/ vereadores-sao-presos-por-corrupcao-no-interior-de-sp-bakcx3wwj3ez2iwo3rgjw8aj2 and http://g1.globo.com/pb/paraiba/noticia/2015/09/ mulher-de-vereador-da-pb-consta-em-lista-de-beneficiarios-do-bolsa-familia. html
} 
one episode of corruption in federal audit reports.

In order to gain insights into the possible mechanism underlying this effect, we investigate other important aspects of the relationship between council size and the public budget. We find that council size affects neither the total revenues nor the total spending of the municipalities. Given the Brazilian context, this could be explained by the fact most municipalities revenues derive from transfers set at the federal level and by the fact that spending is severely constrained by a budget law. In such a way, municipalities have relatively low levels of freedom to raise resources or increase spending through debt. We find, however, that more councilors affect the composition of public spending: municipalities with larger council size devote more resources toward public housing and recreational projects. We interpret this as potentially clientelistic policies. This is consistent with legislators trying to benefit specific areas or citizens through very localized projects, at the expense of the general community (Weingast et al., 1981).

One possible interpretation for these findings is the following. Since the size of the public budget is mostly fixed, adding one extra councilor increase the competition for public resources among legislators, each of which wants to fund projects that benefits her own voters. This causes legislators to spend more time and effort trying to redirect resources to her own voters, possibly by bargaining with the mayor rather than fighting corruption. Moreover, as council size increases each dollar saved from corruption is likely to be spent on projects benefiting other councilors' voters. This constitutes a further reason which could lead legislators to reduce corruption fighting efforts. As a result, the mayor may increase the amount of corruption in response to the fact that councilors devote less effort in overseeing activities. Accordingly, in a larger council the mayor needs the consent of more councilors in order to govern and have his budget approved. Hence, she/he needs to bargain for the support of more councilors. Such a process can lead the mayor to accommodate more clientelistic policies in the budget in order to gain the support of more councilors.

By further analyzing the composition of city council, there's no further 
evidence of significant changes on political selection as council size increases (in terms of education, marital status, and the share of councilors re-elected from the previous term). The only two exceptions are that women participation displays a mild increase, as shown by Correa and Madeira (2014), and that councilors are older in larger councils. Furthermore, we create indices of political fragmentation based on councilors' party and coalition, which are not affected by the increase in council size.

Council productivity is also analyzed. We find that the number of proposed and approved bills (both in absolute terms and per councilor) and the probability that councilors establish a legislative commission decrease with council size. This is consistent both with councilors reducing their effort on tasks not directly related to please their electorate, and with the political process becoming more tedious, forcing the mayor to accommodate more demands from councilors in order to govern. Finally, despite the increase in corruption, further findings are that more councilors do not affect reelection probabilities for councilors or mayors, suggesting that politically accountability is low.

This paper contributes to the literature on corruption, and in particular to the literature on estimating the effects of political institutions on corruption. The previous literature focused on electoral accountability (Ferraz and Finan, 2008), re-election incentives (Ferraz and Finan, 2011), monetary incentives (Di Tella and Schargrodsky, 2003), auditing (Avis et al., 2016), and community monitoring (Olken, 2007). To our knowledge, this is the first attempt to study the role of the legislators on corruption and, in particular, to asses the effects of council size on corruption.

This paper has also an important implication for the literature on legislature size and government spendings. Both the theoretical (Weingast et al., 1981; Primo and Snyder, 2008), and the empirical literature (Bradbury and Crain, 2001; Egger and Koethenbuerger, 2010; Pettersson-Lidbom, 2012) focus exclusively on the effect of legislature size on the amount of spendings. Our data allows us to go beyond the analysis of the size of the budget and to analyze the effect of council size on its composition.

The paper proceeds as follow. In Section 2 we present the institutional 
background. In Section 3 we describe the data and empirical strategy. Results are presented in Section 4. Section 5 concludes

\section{Institutional Background}

The 26 states of Brazil are divided into around 5,500 lower administrative divisions, the municipalities (municipios). These municipalities are autonomous local authorities composed by a mayor (prefeito) and a city council (câmara municipal), both directly elected by the population every four years. Municipal elections take place at the same time all over the country. They follow a majoritarian rule for the mayor, while the city council is selected through an open list proportional representation.

The constitution guarantees a considerable degree of legislative and fiscal autonomy to municipalities: they can legislate on some areas, have the power to collect taxes, and decide how to allocate funds received from the state and the federal government. The constitution imposes some proportion of the municipal budget to be allocated to specific sectors, but generally leaves a high degree of freedom to mayors and legislators (vereadores) to decide how to spend public resources in areas like education, health, and local infrastructure. Each year, the mayor submits an itemized budget proposal to the council. City councilors have the power to impose vetoes to some of the programs and public work projects proposed by the mayor. The latter can allocate resources only to the approved items, and within the limits imposed by the budget. Legislator can also influence public spending by submitting bills, typically to propose new social programs or to request specific public works and services. Moreover, councilors can create specific local councils, generally to monitor the mayor on the implementation of social programs. Finally, legislators are in charge of monitoring and overseeing the mayor for his use of public resources, a duty which possibly limits corruption and irregularities.

An important feature of the legislative body is that the number of councilors is determined by the municipality's population size. Loose limitations on the council size are present already in the 1988 Brazilian Constitution, 
which dictates that municipalities with up to 1 million inhabitants should have between 9 and 21 councilors. However, in the constitution there is no mention of a precise relationship between the number of councilors and the population of the municipalities. In fact, prior to 2004, there was a large room for municipal councils to interpret the rule in different ways and, to a large extent, freely set their own number of seats. However, in March 2004, following a recent Supreme Court decision, the Superior Electoral Tribunal ruled on a strict interpretation of the constitution (Resolution 21,702/2004), which became effective starting from the 2004 election. The resolution establishes a deterministic relationship between the municipality's population and the number of city councilors, in such a way that council size increases at specific population thresholds. Moreover, the resolution specified that population figures must be based on the estimates released by the Brazilian Institute of Geography and Statistic (IBGE) based on the year before each election. Thus, from 2004, there were no longer any margins for municipal councils to set their own number of seats.

\section{Data \& Empirical Strategy}

In order to study the effect of council size on corruption, we take advantage of the fact that from the 2004 election council size is a deterministic and discontinuous function of municipality population: the Electoral Tribunal resolution established that the number of councilors should increase by one every 47,619 inhabitants, starting from 9 councilors for municipalities with less than 47,619 inhabitants. This allow us to implement a sharp regression discontinuity design, where council size is the treatment variable and population size is the running variable. Figure 1 and 2 show the relationship between council seats and population for the 2000 and 2004 election respectively, which allows one to see the contrast in this relationship before and after the 2004 resolution set by the Electoral Tribunal. While for the 2000 election (term 2001-04), the relationship between population and council size is noisy, for the 2004 election (term 2005-08) the number of seats in each council is almost a perfectly de- 
terministic function of the population. We implement the design by applying a local linear regression (LLR) of the following form: ${ }^{3}$

$$
Y_{i}=\beta_{0}+\gamma_{0} D+\beta_{1}\left(\text { pop }_{2003}-t\right)+\gamma_{1}\left(\text { pop }_{2003}-t\right) . D \text { where }|p o p-t| \leq h
$$

Where $Y_{i}$ is the outcome of interest, $\left(\right.$ pop $\left._{2003}-t\right)$ is the IBGE population estimate for the year of 2003 centered around any of the thresholds for council size and $h$ is the bandwidth used in the regression, which is endogenously chosen according to the selector proposed by (Calonico et al., 2014).

In principle, we could exploit all council size thresholds to run the analysis by pooling the data around each threshold. However, since less than $5 \%$ of the 5,562 municipalities are located above the second threshold $(95,239$ inhabitants), there exists a non-negligible risk that pooling the data together will lead to an invalid design. The reason why is that the low number of observations at larger population sizes may not guarantee that observation are quasi-randomly and continuously dispersed around each threshold. Moreover, larger municipalities yield larger values for some outcomes (e.g. total resources and expenditures) and weight strongly on the RDD estimates compared to smaller ones. Such fact potentialize the possible imbalances arising from the low number of observations in the upper range of the data. For this reason we limit our analysis to municipalities around the first population threshold of 47,619 inhabitants. ${ }^{4}$

We gather data on the public finance of municipalities (FINBRA dataset) for the term 2001-04, prior to the policy change (total resources, total expenditure and superavit/deficit) and on few municipality characteristics from the

\footnotetext{
${ }^{3}$ Even though there are ten municipalities which do not perfectly comply with the rule, we still implement a sharp RD design simply because a first stage regression across the threshold estimates a discontinuity extremely close to one, as set by the rule, and highly significant. For example, at the first threshold estimates point to an increase in council size of 0.99703 with t-statistics equal to 310.82 (bandwidth of 10,000). Thus, applying a fuzzy $\mathrm{RD}$ would only increase the magnitude of second stage estimates by an irrelevant small factor. Results using a fuzzy RD design are available upon request.

${ }^{4}$ Nevertheless, results on corruption outcomes are robust to the inclusion of all the population thresholds, and are available upon request
} 
Census 2000 (labor force participation, income and population average years of schooling) to test for the validity of the design. RD estimates as specified above, displayed in Table 1, show that using all thresholds together indeed lead to sizeable imbalances in covariates, invalidating the design. ${ }^{5}$ On the other hand, estimates around the first threshold alone, which covers $95 \%$ of the municipalities, leads to a robust research design since the analysis on these variables do not point for any statistically significant differences around the threshold. Henceforth, we decide to use only the first threshold to perform the analysis.

A further important test on the validity of the design is assessing the continuity of density function of municipality population around the threshold. Such test is informative on specific types of manipulation which could be performed by councilors or mayors in an attempt to increase or decrease council size. A first important consideration regarding this hypothesis is that population estimates are conducted by IBGE which is an independent federal institution and unlikely to be influenced by politicians acting at relatively small municipalities. A second relevant consideration is that population figures used for the 2004 election were based on 2003. Such estimates were published still in the same year of 2003, prior to the decision of the Electoral Tribunal setting council size for the 2004 election. It is therefore highly unlikely that any municipality was able to manipulate population figures in order to fall on a given side of the threshold. Figure 3 displays the distribution of municipalities over IBGE population estimates for 2003, together with the results from the density discontinuity test proposed by McCrary (2008). This evidence strongly suggests that the density function is indeed continuous around the threshold. Together with the evidence on the balance of covariates prior to the policy change, it lends strong support for the validity of the design.

In the next section, we proceed with the analysis on a number of outcomes which are gathered from a variety of sources. Data on corruption comes from

\footnotetext{
${ }^{5}$ Indeed, Cepaluni and Mignozzetti (2015) exploits the same policy experiment but implement an analysis on pooled data around all the thresholds. We argue that such design is invalid due to these large disparities in these outcomes, prior to the policy change.
} 
Brollo et al. (2013), who use audits by the Comptroller General of the Union (CGU) to build a measure of corruption at the municipality level. ${ }^{6}$ It contains information from the 2nd to the 29th lottery which randomly selects municipalities for audits. When we analyze corruption, our sample is thus limited to those municipalities which were audited in one of these lotteries. ${ }^{7}$ An interesting feature of the data is that these audits took place from 2003 to 2009, which allows us to test whether there were differences in corruption levels at the threshold before the changes in council size in 2004 as a placebo test. Data on population estimates for 2003 comes from the Brazilian Institute of Geography and Statistics (IBGE), while detailed information on public finance comes from the FINBRA dataset. Information on legislative productivity is based on the Interlegis survey conducted at all the Brazilian municipality councils in 2005 and electoral data is downloaded from the Superior Electoral Tribunal.

\footnotetext{
${ }^{6}$ For more details on this anti-corruption program see Avis et al. (2016); Brollo et al. (2013); Ferraz and Finan (2008, 2011).

${ }^{7}$ It is worth noting that for 10 out of the 26 states we are able to recall pre-existing rules set by state level legislation linking council size to population. In the data, within each of these states, most of the thresholds are very imperfectly enforced and none of them perfectly coincides with those set by the Electoral Tribunal in 2004. Nevertheless, some are relatively close. This poses a potential threat to our identification strategy, since some of the pre-existing thresholds might be interfering with our results. In particular, previous discontinuities in council size might result in pre-existing discontinuities in corruption outcomes, which can perpetuates over time. For this reason, we assess carefully the relationship between population and corruption outcomes prior to 2004 in these ten states, and decide to drop from our analysis two states (Bahia and Parana) in which there were pre-existing discontinuities in corruption levels coinciding with population threshold. By dropping this two states, in our final sample we can reliably attribute any result in corruption outcomes after the 2004 election to the changes in council size set in the same year and contrast these results to the fact that there were no pre-existing discontinuities in corruption level prior to 2004. Nevertheless, it is worth noting that results only become stronger when including those two states in our main analysis. These results on the full sample are available upon request.
} 


\section{Results}

\subsection{Corruption}

We begin by studying the effect of council size on corruption. Following Brollo et al. (2013), we use two binary variables as measures of corruption. A municipality is said to have experience broad corruption if there was at least one episode of illegal procurement practice, fraud, favoritism, over-invoicing, diversion of funds, or non-proven expenses. The narrow corruption measure takes into account only episodes of severe illegal procurement practice, fraud, favoritism, over-invoicing.

Figures 4 and 5 show how broad and narrow corruption measures based on audits during the 2005-2008 term evolve around the threshold on population size. They document a substantial positive discontinuity in the incidence of corruption episodes around the population threshold at which the number of city councilors increases from 9 to 10. Thus, this evidence indicates that an extra councilor is associated with an increase in the incidence of both broad and narrow corruption.

Panel A of Table 2 presents RD estimates for the same measures and shows that an extra councilor raises the incidence of broad corruption by about 60 percentage points, and the incidence of narrow corruption by about 80 percentage points. In order to assess whether these results are driven by the specific bandwidths endogenously selected, we replicate the local linear estimates for a range of bandwidths. These results are presented in the Appendix Table A.1 and show that the strong positive results from Table 2 are not driven by a specific bandwidth choice. In the same table, panel $\mathrm{C}$ and $\mathrm{D}$ report the results for the same estimates with the inclusion of controls which include 26 state fixed-effects, dummies for the number of seats in the 2000 elections (pre-policy) and for other population thresholds determining federal transfers, caps of councilors' wage, and previous state pre-existing thresholds for council size, if any. While none of these thresholds coincide with the policy threshold exploited in this analysis, some of them are in the same neighborhood and could be driving the results from above. However, the evidence presented in 
panel $\mathrm{C}$ and $\mathrm{D}$ shows that including these controls only makes the findings on corruption stronger. We interpret this as strong evidence that the existence of other population based policies is not a reason of concern for identification.

Further evidence on the robustness of these findings is presented in Panel B of Table 2, which offers a placebo test by replicating the baseline specification from Panel A for the term 2001-2004. This is the term right before the policy change, in which there is no discontinuity in council size at the population threshold. Consistently, we do not find any evidence of discontinuities for any of the corruption measures around the threshold. This lends extra credibility to our conclusion that a larger council size causally leads to more corruption.

\subsection{Public Spending \& Composition}

In order to shed light on the mechanisms which drive the effect on corruption, we study whether the number of councilors affects the public budget. First, we investigate whether adding an extra councilor affects the size of the budget and total spending. In a seminal paper, Weingast et al. (1981) predicts a positive relationship between the size of the legislature and public spending. In Table 3 , we present $\mathrm{RD}$ estimates of the effect of council size on total resources, total expenditures and superavit/deficit. Interestingly, results indicates that larger council has no statistically significant effect on any these variables. This is consistent with the idea that the Brazilian municipalities have little space to influence the size of the public budget for mainly two reasons. First, since the 2000 there is a fiscal law which forbids municipalities from spending more than their revenues in a fiscal year, and holds mayors criminally liable for violations. Second, while it would still be possible for the legislature to raise taxes to finance spending, federal transfers respond for the largest share of the municipalities budget, especially in small ones. ${ }^{8}$ Thus, any attempt to raise revenues through taxes have a limited impact on the budget.

Second, we study whether council size has an effect on the composition of public spending. The first four columns of Table 4 present RDD estimates of

\footnotetext{
${ }^{8}$ Brollo et al. (2013) reports that for municipalities with less than 50,000 inhabitants, only $6 \%$ of the budget derives from local taxes.
} 
the relationship between council size and (the log of) four types of expenditures: urban, habitational, agricultural, and free time. ${ }^{9}$ There is a positive effect of council size on all of these types of expenditures: once we aggregate all of them, we find that having an extra councilor increases expenditures on these four categories by $33 \%$ (column 5), while all other expenditures do not diminish substantially (column 6). We interpret this type of expenditures as potentially clientelistic, in the sense that they can be targeted to specific individuals or areas of the municipality in exchange for political support. Consistently, we also find that having an extra councilor increases the probability that the municipality builds and assigns new public houses, and decreases the presence of slums (see Appendix Table A.2 for details).

\subsection{Legislative Production}

We further analyze the effect of council size on the productivity of the city council. Table 5 presents RDD estimates on the relationship between council size and the number of bills proposed and approved by councilors (both in total and per councilor), the probability that councilors establish a commission, and the probability that councilors establish a urban council. We find that larger councils are associated with a lower total number of bills submitted and approved, even though this relationship is not statistically significant. Instead, if we consider bills per councilors, effects on the same measures are negative and border line statistically significant at the $10 \%$ level. ${ }^{10}$ Moreover, an extra councilor reduces the likelihood that the city council establishes commissions and urban councils. A possible interpretation for these findings is that adding an extra councilor makes the political process more tiresome as it is more difficult to find agreement between a larger numbers of legislators.

\footnotetext{
${ }^{9} \mathrm{We}$ also estimate the relationship of council size on other types of expenditures (like administration, health, education and transportation), but do not find any significant effect. Result for these other types of expenditures are available upon request.

${ }^{10} \mathrm{CCT}$ robust p-values are 0.083 and 0.160 for submitted and approved bills per seat, respectively.
} 


\subsection{Political Selection and Fragmentation}

Tables 6 and 7 present additional results on how an extra seat may influence the composition of the council. Table 6 shows that the observable characteristics of elected councilors are not strongly affected. Councilors' demographics such as years of education and marital status are not different across the threshold. The same is true for the number of reelected councilors, which is not affected by council size. The only detected differences are the probability that there is at least one woman in the council and average councilor age, which is higher in municipalities with an extra seat.

In order to study whether political fragmentation is affected, we create a fractionalization measure of parties and coalitions in the council, based on the Herfindahl-Hirschman Index. ${ }^{11}$ Furthermore, we study whether the number of parties or coalitions represented in the council change. Table 7 shows $\mathrm{RD}$ estimates on these measures. These results do not support the hypothesis that council fragmentation is affected by the inclusion of an additional councilor. Overall, this evidence suggests that changes in political selection and fragmentation are minor and unlikely to explain the results on corruption outcomes.

\section{Conclusion}

This paper provides robust evidence that the addition of a seat in the council of Brazilian municipalities causes an increase in the incidence of corruption, as measured the federal audits. While the mechanisms driving such effects cannot be easily identified in the data, we provide further suggestive evidence which reveals further aspects of the municipalities which are and are not affected by a larger council size. Such additional evidence helps shedding light on the potential mechanism driving the strong results on corruption.

The results showing no significant effects on the total budget or on public spending indicate that the findings on corruption are not simply driven by

\footnotetext{
${ }^{11}$ The index is computed as the $\sum_{1}^{N} s_{i}\left(1-s_{i}\right) /(1-1 / N)$, where $s_{i}$ is the share of councilors belonging to party or coalition $i$.
} 
increased fiscal profligacy caused by larger legislature size (the "law of $1 / \mathrm{n}$ " Weingast et al. (1981)). Moreover, the evidence on political selection and fragmentation does not seem to be able to explain changes in corruption outcomes either.

While we do not advocate for one exclusive mechanism as the driver of these results, one possible interpretation of the findings on corruption is the following. Adding one extra councilor increases the competition for public resources among legislators who aim to redirect spending toward their electorate, especially if one considers that there is not much room for increasing spending due to the presence of a binding budget law. This increases the competition amongst councilors for allocating the public spending according to their interest. Furthermore, at the individual level, fighting corruption becomes less attractive for councilors since one dollar saved from corruption is now divided by more councilors. As results, councilors may respond to an increase in council size by fighting less intensily corruption and by devoting more effort to allocate the budget toward their electorate. Such mechanisms are not only able to explain the rise in corruption but are also consistent with the findings that budget composition shifts towards potentially clientelistic spending, such as public housing and recreation.

A further consistent, and not exclusive, explanation for these findings is that an extra councilor renders the political process more tedious, as it is harder to find agreement amongst more councilors. As a result, it may become more difficult for the mayor to implement his political agenda, as she/he now needs the support of a larger number of councilors. This may cause her/him to be more lenient toward the political interests of councilors in exchange for political support. Such increased exchange of political favors may result in a larger share of the budget devoted to clientelistic policies and in increased levels of corruption.

We conclude by pointing out that more research is need to understand whether these findings apply to other contexts and to individuate the specific mechanisms driving the corruption rise. 


\section{References}

Avis, Eric, Claudio Ferraz, and Frederico Finan, "Do Government Audits Reduce Corruption? Estimating the Impacts of Exposing Corrupt Politicians," Working Paper 22443, National Bureau of Economic Research July 2016.

Barnett, William A, Melvin Hinich, and Norman Schofield, Political Economy: Institutions, Competition and Representation: Proceedings of the Seventh International Symposium in Economic Theory and Econometrics, Vol. 7, Cambridge University Press, 1993.

Barro, Robert J, "The control of politicians: an economic model," Public choice, 1973, 14 (1), 19-42.

Bradbury, John Charles and W.Mark Crain, "Legislative organization and government spending: cross-country evidence," Journal of Public Economics, 2001, 82 (3), $309-325$.

Brollo, Fernanda, Tommaso Nannicini, Roberto Perotti, and Guido Tabellini, "The Political Resource Curse," American Economic Review, August 2013, 103 (5), 1759-96.

Calonico, Sebastian, Matias D Cattaneo, and Rocio Titiunik, "Robust Nonparametric Confidence Intervals for Regression-Discontinuity Designs," Econometrica, 2014, 82 (6), 2295-2326.

Cepaluni, Gabriel and Umberto G Mignozzetti, "Politicians Matter: Legislature Size and Welfare with Evidence from Brazil," Available at SSRN 2594318, 2015.

Correa, Gabriel and Ricardo A. Madeira, "The Size of Local Legislatures and Women's Political Representation: Evidence from Brazil," Working Papers, Department of Economics 2014(04), University of So Paulo (FEAUSP) 2014.

Egger, Peter and Marko Koethenbuerger, "Government Spending and Legislative Organization: Quasi-experimental Evidence from Germany," American Economic Journal: Applied Economics, October 2010, 2 (4), 200212.

Ferejohn, John, "Incumbent performance and electoral control," Public choice, 1986, 50 (1), 5-25. 
Ferraz, Claudio and Frederico Finan, "Exposing Corrupt Politicians: The Effects of Brazil's Publicly Released Audits on Electoral Outcomes," The Quarterly Journal of Economics, 2008, 123 (2), 703-745.

_ and _, "Electoral Accountability and Corruption: Evidence from the Audits of Local Governments," American Economic Review, 2011, 101 (4), $1274-1311$.

_ , _ , and Diana B. Moreira, "Corrupting learning: Evidence from missing federal education funds in Brazil," Journal of Public Economics, 2012, 96 (910), $712-726$.

McCrary, Justin, "Manipulation of the running variable in the regression discontinuity design: A density test," Journal of Econometrics, 2008, 142 (2), 698-714.

Olken, Benjamin A., "Monitoring Corruption: Evidence from a Field Experiment in Indonesia," Journal of Political Economy, 2007, 115, 200-249.

_ , "Corruption perceptions vs. corruption reality," Journal of Public Economics, August 2009, 93 (7-8), 950-964.

- and Rohini Pande, "Corruption in Developing Countries," Annual Review of Economics, 07 2012, 4 (1), 479-509.

Pettersson-Lidbom, Per, "Does the size of the legislature affect the size of government? Evidence from two natural experiments," Journal of Public Economics, 2012, 96 (34), $269-278$.

Primo, David M. and James M. Jr. Snyder, "Distributive Politics and the Law of 1/n," The Journal of Politics, 4 2008, 70, 477-486.

Tella, Rafael Di and Ernesto Schargrodsky, "The Role of Wages and Auditing during a Crackdown on Corruption in the City of Buenos Aires," Journal of Law \&3 Economics, April 2003, 46 (1), 269-92.

Weingast, Barry, Kenneth A Shepsle, and Christopher Johnsen, "The Political Economy of Benefits and Costs: A Neoclassical Approach to Distributive Politics," Journal of Political Economy, 1981, 89 (4), 642-64. 


\section{Figures and Tables}

Figure 1: Seats 2000

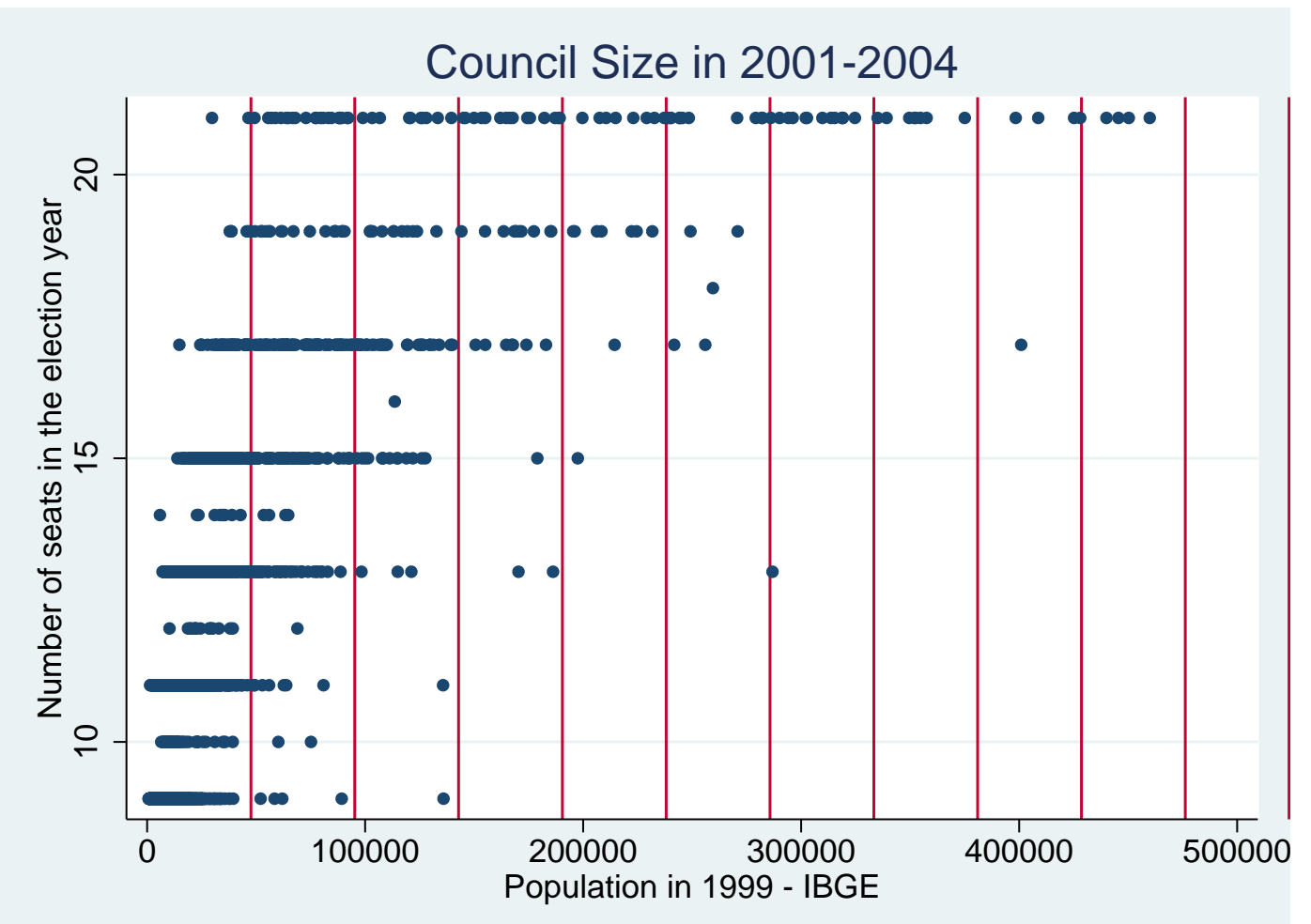

Notes: This figure presents the relationship between the municipal population and the number of seats in the city council available in the election year before the Superior Electoral Tribunal resolution of 2004 establishing a precise relationship between council size and municipal population (as estimated by IBGE for the year before the election). The election took place in 2000, for the political term 2001-2004. The population estimate is for 1999. Vertical red lines corresponds to the population thresholds established by the 2004 resolution (every 47,619 inhabitants). 
Figure 2: Seats 2004

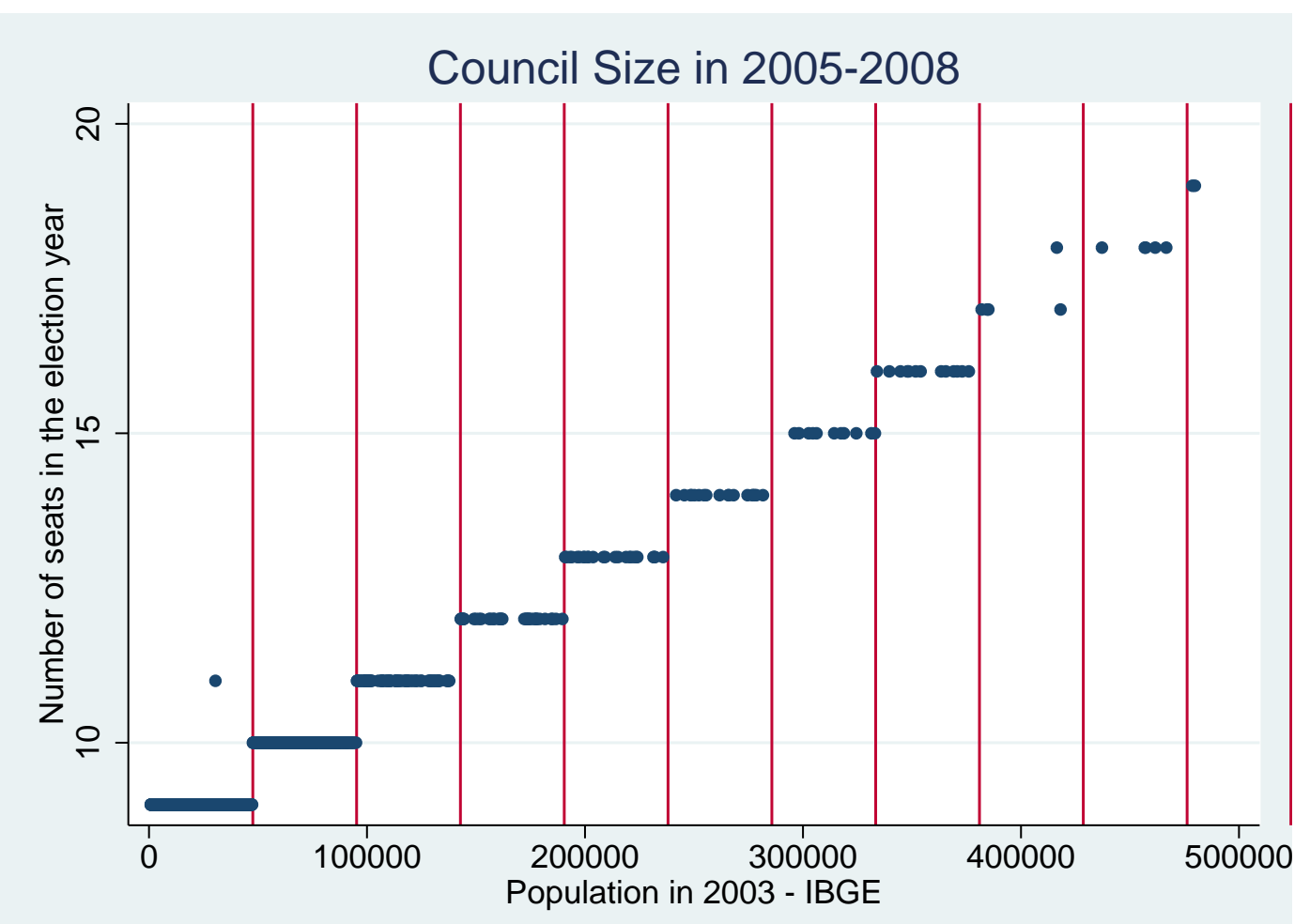

Notes: This figure presents the relationship between the municipal population and the number of seats in the city council available in the election year right after the Superior Electoral Tribunal resolution of 2004 establishing a precise relationship between council size and municipal population (as estimated by IBGE for the year before the election). The election took place in 2004, for the political term 2005-2008. The population estimate is for 2003. Vertical red lines corresponds to the population thresholds established by the 2004 resolution (every 47,619 inhabitants). 
Figure 3: Population Density

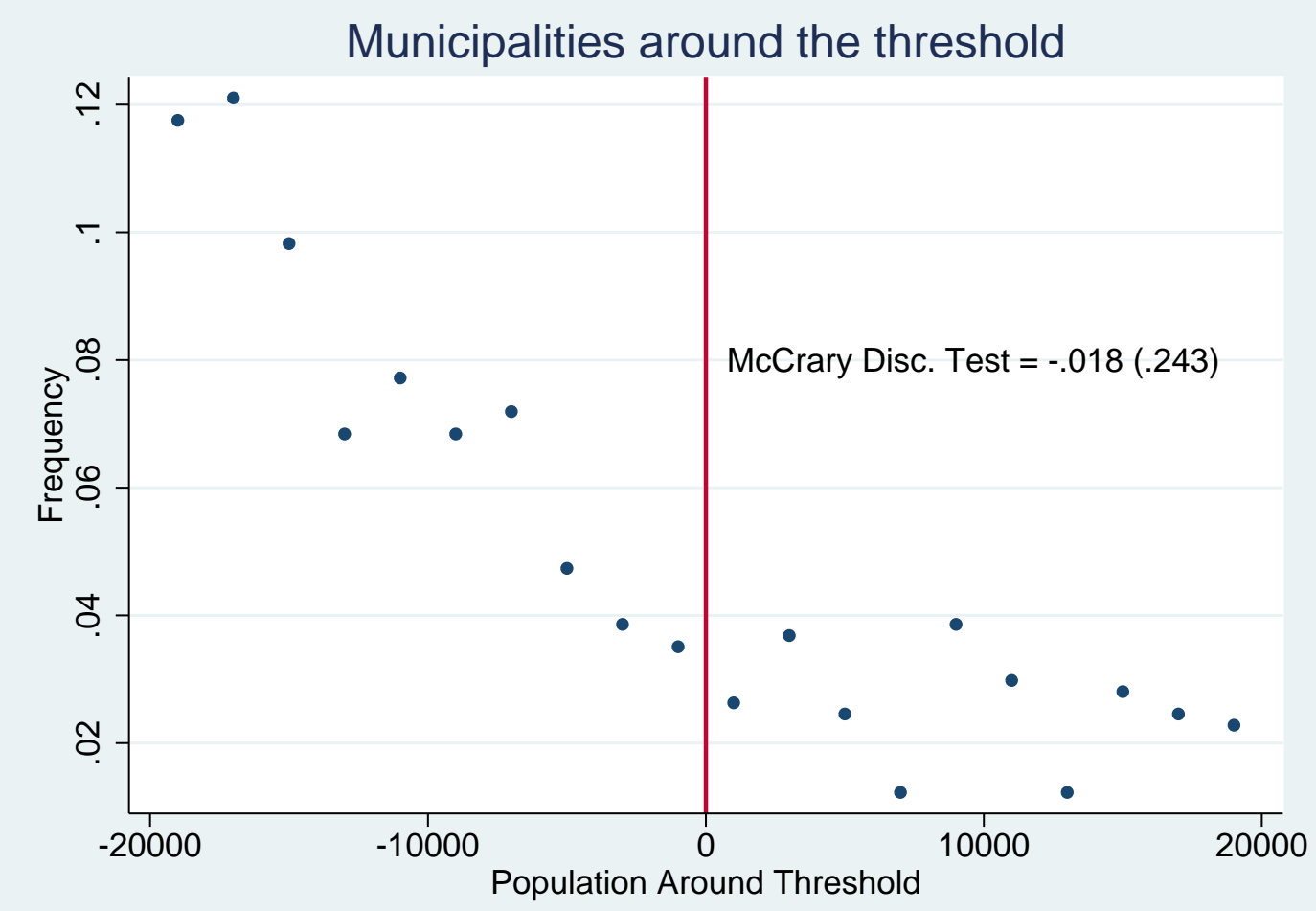

Notes: This figure presents the distribution of municipalities over IBGE population estimates for 2003, for municipalities in a range of 20,000 inhabitants above or below the first threshold of 47,619 inhabitants. The figure also displays the results from the density discontinuity test proposed by McCrary (2008) (standard errors within brackets). 
Figure 4: RDD Broad Corruption

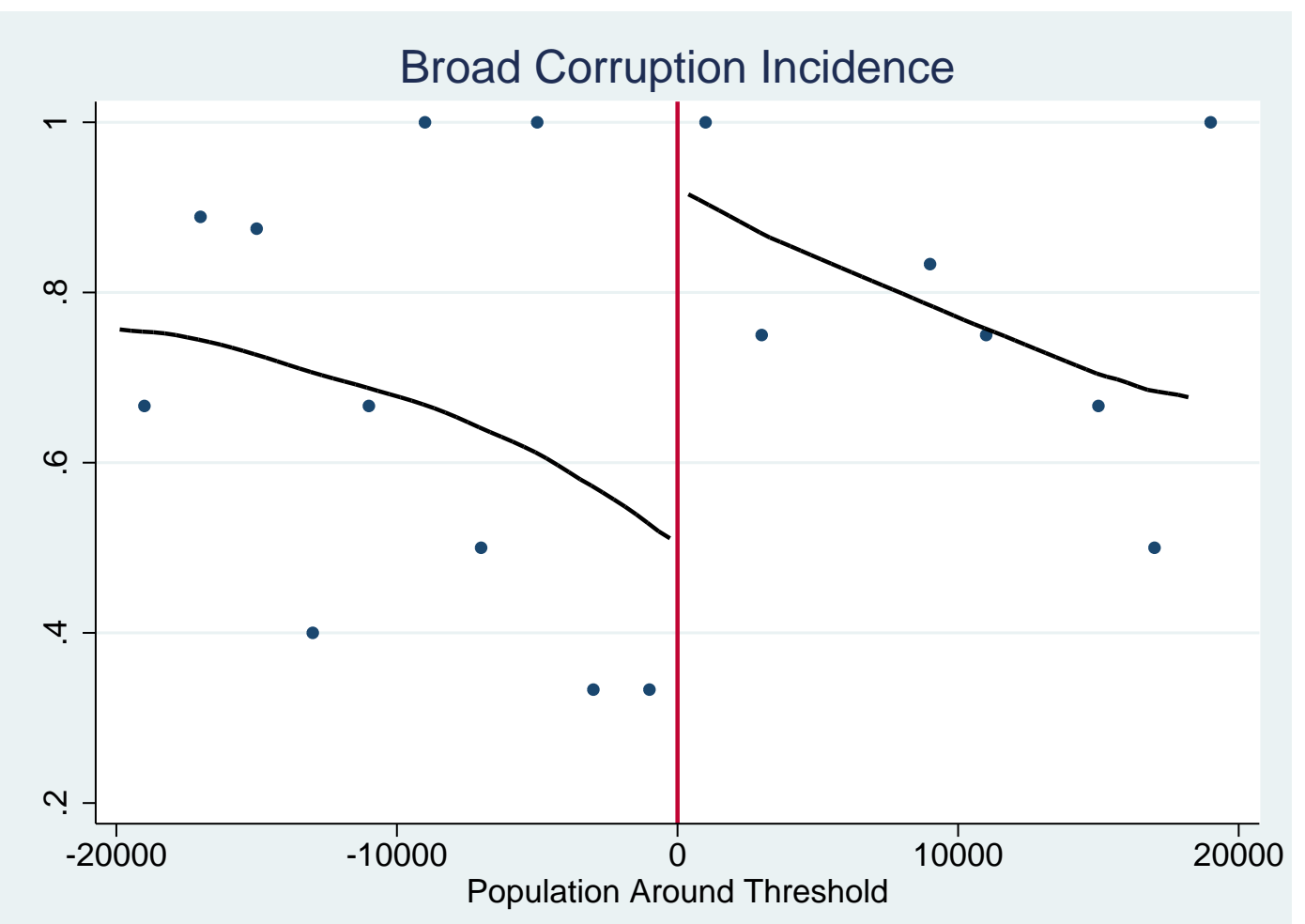

Notes: The figure displays the relationship between council size and a measure of broad corruption. The black curves display a local linear polynomial smoothing. Bandwidths for this nonparametric estimation are endogenously selected using the procedure proposed by Calonico et al. (2014). 
Figure 5: RDD Narrow Corruption

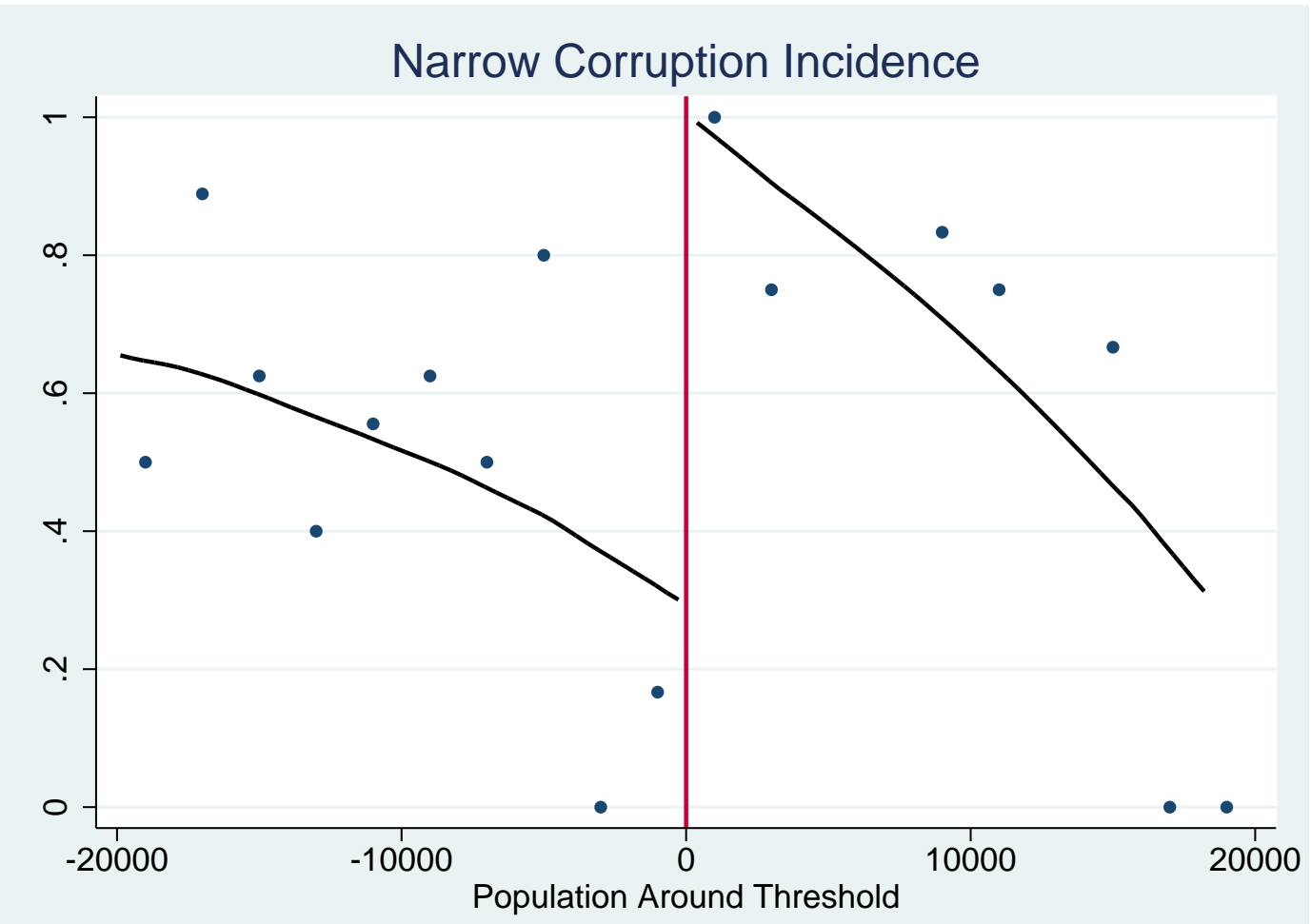

Notes: The figure displays the relationship between council size and a measure of narrow corruption. The black curves display a local linear polynomial smoothing. Bandwidths for this nonparametric estimation are endogenously selected using the procedure proposed by Calonico et al. (2014). 
Table 1: Balance of Covariates Around Threshold

\begin{tabular}{|c|c|c|c|c|c|c|}
\hline Dependent variable & Total & Total & Superavit & Labor Force & Log Income & Years of \\
\hline Dependent variable & Resources & Expenditures & Deficit & Participation & Per Capita & Schooling \\
\hline & $(1)$ & $(2)$ & $(3)$ & $(4)$ & $(5)$ & $(6)$ \\
\hline \multicolumn{7}{|c|}{ Panel A: Only First Threshold } \\
\hline Estimated Discontinuity & 0.007 & 0.005 & 0.012 & 0.027 & 0.073 & 0.042 \\
\hline (conventional std er) & $(0.097)$ & $(0.096)$ & $(0.008)$ & $(0.018)$ & $(0.126)$ & $(0.308)$ \\
\hline CCT Robust Confidence Interval & {$[-0.215,0.237]$} & {$[-0.229,0.217]$} & {$[-0.004,0.033]$} & {$[-0.009,0.075]$} & {$[-.186,0.416]$} & {$[-0.166,1.234]$} \\
\hline Bandwidth & 11034 & 10845 & 11591 & 15287 & 14842 & 15302 \\
\hline $\mathrm{N}$ & 264 & 262 & 283 & 373 & 357 & 373 \\
\hline \multicolumn{7}{|c|}{ Panel B: All Thresholds } \\
\hline Estimated Discontinuity & 0.517 & 0.501 & 0.015 & 0.038 & 0.248 & 0.593 \\
\hline (conventional std er) & $(0.214)$ & $(0.213)$ & $(0.009)$ & $(0.015)$ & $(0.109)$ & $(0.273)$ \\
\hline CCT Robust Confidence Interval & {$[0.101,1.076]$} & {$[0.082,1.055]$} & {$[-0.001,0.037]$} & {$[0.011,0.076]$} & {$[0.065,0.543]$} & {$[0.106,1.332]$} \\
\hline Bandwidth & 10524 & 10456 & 11231 & 11349 & 12798 & 12398 \\
\hline $\mathrm{N}$ & 381 & 379 & 406 & 413 & 467 & 348 \\
\hline
\end{tabular}

Notes: The table displays discontinuities estimates at the population thresholds set by the 2004 TSE Resolution, based on a local linear regression as in equation (1). Bandwidths are endogenously selected and bias robust confidence intervals are calculated as proposed by Calonico et al. (2014). Panel A uses only the observations around the first population threshold, while Panel B uses observations pooled around all thresholds. 
Table 2: Council Size and Corruption

\begin{tabular}{|c|c|c|}
\hline Dependent variable & $\begin{array}{c}\text { Broad Corruption } \\
\text { (1) }\end{array}$ & $\begin{array}{c}\text { Narrow Corruption } \\
(2)\end{array}$ \\
\hline \multicolumn{3}{|c|}{ 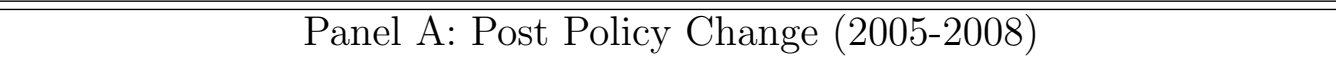 } \\
\hline $\begin{array}{l}\text { Estimated Discontinuity } \\
\text { (conventional std er) }\end{array}$ & $\begin{array}{c}0.615 \\
(0.182)\end{array}$ & $\begin{array}{c}0.808 \\
(0.164)\end{array}$ \\
\hline CCT Robust Confidence Interval & {$[0.258,1.033]$} & {$[0.490,1.191]$} \\
\hline Bandwidth & 16489 & 14889 \\
\hline $\mathrm{N}$ & 78 & 69 \\
\hline \multicolumn{3}{|c|}{$\begin{array}{l}\text { Panel B: Pre Policy Change (2001-2004) } \\
\end{array}$} \\
\hline $\begin{array}{l}\text { Estimated Discontinuity } \\
\text { (conventional std er) }\end{array}$ & $\begin{array}{c}0.030 \\
(0.069)\end{array}$ & $\begin{array}{c}0.045 \\
(0.231)\end{array}$ \\
\hline CCT Robust Confidence Interval & {$[-.151,0.182]$} & {$[-0.591,0.433]$} \\
\hline Bandwidth & 7869 & 12574 \\
\hline & 47 & 69 \\
\hline
\end{tabular}

Notes: The table displays discontinuities estimates at the population thresholds set by the 2004 TSE Resolution, based on a local linear regression as in equation (1). Bandwidths are endogenously selected and 95\% bias robust confidence intervals are calculated as proposed by Calonico et al. (2014). 
Table 3: Council Size and Public Budget

\begin{tabular}{lccc}
\hline Dependent variable & Total Resources & Total Expenditures & Superavit/Deficit \\
\hline & $(1)$ & $(2)$ & $(3)$ \\
\hline Estimated Discontinuity & 0.014 & 0.016 & 0.001 \\
(conventional std er) & $(0.094)$ & $(0.090)$ & $(0.012)$ \\
CCT Robust Confidence Interval & {$[-0.198,0.240]$} & {$[-0.182,0.232]$} & {$[-0.029,0.031]$} \\
& & & \\
& 10980 & 10856 & 14280 \\
Bandwidth & 264 & 263 & 339 \\
$\mathrm{~N}$ & Notes: The table displays discontinuities estimates at the population thresholds set by the \\
2004 TSE Resolution, based on a local linear regression as in equation (1). Bandwidths are \\
endogenously selected and 95\% bias robust confidence intervals are calculated as proposed by \\
Calonico et al. (2014).
\end{tabular}


Table 4: Council Size and Spending Composition

\begin{tabular}{lcccccc}
\hline Dependent variable & Urban & Habitational & Agricultural & Free Time & Sum Clientelisic & Other \\
\hline & $(1)$ & $(2)$ & $(3)$ & $(4)$ & $(5)$ & $(6)$ \\
\hline Estimated Discontinuity & 0.298 & 1.825 & 1.301 & 1.227 & 0.329 & -0.014 \\
(conventional std er) & $(0.189)$ & $(1.053)$ & $(0.691)$ & $(0.653)$ & $(0.173)$ & $(0.087)$ \\
CCT Robust Confidence Interval & {$[-0.057,0.783]$} & {$[-0.721,4.299]$} & {$[-0.377,2.961]$} & {$[-0.070,3.054]$} & {$[0.004,0.774]$} & {$[-0.212,0.188]$} \\
& & & & & & \\
Bandwidth & 10651 & 19217 & 16074 & 14541 & 9660 & 11421 \\
N & 255 & 532 & 408 & 344 & 217 & 276 \\
\hline
\end{tabular}

Notes: The table displays discontinuities estimates at the population thresholds set by the 2004 TSE Resolution, based on a local linear regression as in equation (1). Bandwidths are endogenously selected and $95 \%$ bias robust confidence intervals are calculated as proposed by Calonico et al. (2014). 
Table 5: Council Size and Legislature Productivity

\begin{tabular}{|c|c|c|c|c|c|c|}
\hline Dependent variable & Bills Proposed & Bills Approved & $\begin{array}{l}\text { Bills Proposed } \\
\text { per Councilor }\end{array}$ & $\begin{array}{l}\text { Bills Approved } \\
\text { per Councilor }\end{array}$ & Commission & Urban Council \\
\hline & $(1)$ & $(2)$ & $(3)$ & (4) & $(5)$ & (6) \\
\hline Estimated Discontinuity & -6.485 & -2.880 & -0.861 & -0.426 & -0.265 & -0.170 \\
\hline (conventional std er) & $(5.016)$ & $(2.827)$ & $(0.539)$ & $(0.297)$ & $(0.116)$ & $(0.109)$ \\
\hline CCT Robust Confidence Interval & {$[-20.174,3.018]$} & {$[-10.312,3.105]$} & {$[-2.339,0.143]$} & {$[-1.218,0.201]$} & {$[-0.584,-0.046]$} & {$[-0.461,0.048]$} \\
\hline Bandwidth & 12578 & 12171 & 12652 & 12533 & 10488 & 17799 \\
\hline $\mathrm{N}$ & 274 & 257 & 278 & 261 & 237 & 475 \\
\hline
\end{tabular}

regression as in equation (1). Bandwidths are endogenously selected and $95 \%$ bias robust confidence intervals are calculated as proposed by Calonico et al. (2014). 
Table 6: Council Size and Political Selection

\begin{tabular}{|c|c|c|c|c|c|c|}
\hline Dependent variable & $\begin{array}{l}\text { At least one } \\
\text { woman }\end{array}$ & $\begin{array}{l}\text { Share of } \\
\text { Females }\end{array}$ & $\begin{array}{c}\text { Years of } \\
\text { Education }\end{array}$ & Age & Married & $\begin{array}{l}\text { Number of } \\
\text { Reelected }\end{array}$ \\
\hline & $(1)$ & $(2)$ & $(3)$ & $(4)$ & $(5)$ & $(6)$ \\
\hline Estimated Discontinuity & -0.232 & 0.029 & -0.583 & 3.265 & 0.052 & 0.207 \\
\hline (conventional std er) & $(0.134)$ & $(0.027)$ & $(0.529)$ & $(1.178)$ & $(0.055)$ & $(0.405)$ \\
\hline CCT Robust Confidence Interval & {$[-0.575,0.095]$} & {$[-0.036,0.096]$} & {$[-1.920,0.699]$} & {$[1.134,6.466]$} & {$[-0.078,0.181]$} & {$[-1.301,0.688]$} \\
\hline Bandwidth & 16681 & 19711 & 18807 & 6581 & 16039 & 16064 \\
\hline $\mathrm{N}$ & 298 & 374 & 352 & 97 & 295 & 312 \\
\hline
\end{tabular}

Notes: The table displays discontinuities estimates at the population thresholds set by the 2004 TSE Resolution, based on a local linear regression as in equation (1). Bandwidths are endogenously selected and $95 \%$ bias robust confidence intervals are calculated as proposed by Calonico et al. (2014).

Table 7: Council Size and Political Fragmentation

\begin{tabular}{lcccc}
\hline Dependent variable & $\begin{array}{c}\text { HH Frac. Index } \\
\text { Parties }\end{array}$ & $\begin{array}{c}\text { Number of } \\
\text { Parties }\end{array}$ & $\begin{array}{c}\text { HH Frac. Index } \\
\text { Coalitions }\end{array}$ & $\begin{array}{c}\text { Number of } \\
\text { Coalitions }\end{array}$ \\
\hline & $(1)$ & $(2)$ & $(3)$ & $(4)$ \\
\hline Estimated Discontinuity & -0.003 & 0.438 & -0.019 & 0.369 \\
(conventional std er) & $(0.011)$ & $(0.357)$ & $(0.013)$ & $(0.256)$ \\
CCT Robust Confidence Interval & {$[-0.028,0.025]$} & {$[-0.370,1.329]$} & {$[-0.048,0.011]$} & {$[-0.246,0.979]$} \\
& & & & \\
Bandwidth & 18419 & 18491 & 15647 & 15674 \\
N & 494 & 497 & 387 & 389 \\
\hline
\end{tabular}

Notes: The table displays discontinuities estimates at the population thresholds set by the 2004 TSE Resolution, based on a local linear regression as in equation (1). Bandwidths are endogenously selected and $95 \%$ bias robust confidence intervals are calculated as proposed by Calonico et al. (2014). "HH. Frac. Index" refers to the normalized Herfindahl-Hirschman Fractionalization Index computed as $\sum_{1}^{N} s_{i}(1-$ $\left.s_{i}\right) /(1-1 / N)$, where $s_{i}$ is the share of councilors belonging to party or coalition $i$. 


\section{Appendix Figures and Tables}

Table A.1: Bandwidth Selection

\begin{tabular}{lccccc}
\hline Bandwidth & 10000 & 12500 & 15000 & 17500 & 20000 \\
\hline \hline \multicolumn{7}{c}{$(1)$} & $(2)$ & $(3)$ & $(4)$ & $(5)$ \\
\hline Panel A: Broad Corruption without Controls \\
Estimated Discontinuity & $0.745^{* * *}$ & $0.609^{* *}$ & $0.500^{*}$ & $0.596^{* *}$ & $0.471^{* *}$ \\
(conventional std er) & $(0.207)$ & $(0.205)$ & $(0.196)$ & $(0.182)$ & $(0.175)$ \\
\hline \hline \multicolumn{7}{c}{ Panel B: Narrow Corruption without Controls } \\
\hline Estimated Discontinuity & $0.848^{* * *}$ & $0.781^{* * *}$ & $0.750^{* * *}$ & $0.845^{* * *}$ & $0.764^{* * *}$ \\
(conventional std er) & $(0.193)$ & $(0.184)$ & $(0.176)$ & $(0.170)$ & $(0.165)$ \\
\hline \multicolumn{7}{c}{} \\
\hline \hline \multicolumn{7}{c}{ Panel C: Broad Corruption with Controls } \\
\hline Estimated Discontinuity & 0.544 & $0.739^{*}$ & $0.808^{*}$ & $0.925^{* * *}$ & $0.821^{* *}$ \\
(conventional std er) & $(0.551)$ & $(0.343)$ & $(0.310)$ & $(0.248)$ & $(0.251)$ \\
\hline \multicolumn{7}{c}{} \\
\hline \hline
\end{tabular}

Notes: The table displays discontinuities estimates at the population thresholds set by the 2004 TSE Resolution, based on a local linear regression as in equation (1) for a range of bandwidths. 
Table A.2: Council Size and Public Housing

\begin{tabular}{lcc}
\hline Dependent variable & Public Housing & Slums \\
\hline & $(1)$ & $(2)$ \\
\hline $\begin{array}{l}\text { Estimated Discontinuity } \\
\text { (conventional std er) }\end{array}$ & 0.233 & -0.243 \\
CCT Robust Confidence Interval & {$[0.043,0.487]$} & $(0.140)$ \\
& 13672 & 11579 \\
Bandwidth & 325 & 286 \\
$\mathrm{~N}$ & & \\
Notes: The table displays discontinuities estimates at the population \\
thresholds set by the 2004 TSE Resolution, based on a local linear \\
regression as in equation (1). Bandwidths are endogenously selected \\
and 95\% bias robust confidence intervals are calculated as proposed \\
by Calonico et al. (2014). "Public Housing" is a dummy for whether \\
any new public houses were built and assigned in 2008. "Slums" is a \\
dummy indicating the presence of slums in the municipality.
\end{tabular}




\section{Working Paper del Dipartimento di Economia e Finanza}

1. L. Colombo, H. Dawid, Strategic Location Choice under Dynamic Oligopolistic Competition and Spillovers, novembre 2013.

2. M. Bordignon, M. Gamalerio, G. Turati, Decentralization, Vertical Fiscal Imbalance, and Political Selection, novembre 2013.

3. M. Guerini, Is the Friedman Rule Stabilizing? Some Unpleasant Results in a Heterogeneous Expectations Framework, novembre 2013.

4. E. Brenna, C. Di Novi, Is caring for elderly parents detrimental to women's mental health? The influence of the European North-South gradient, novembre 2013.

5. F. Sobbrio, Citizen-Editors' Endogenous Information Acquisition and News Accuracy, novembre 2013.

6. P. Bingley, L. Cappellari, Correlation of Brothers Earnings and Intergenerational Transmission, novembre 2013.

7. T. Assenza, W. A. Brock, C. H. Hommes, Animal Spirits, Heterogeneous Expectations and the Emergence of Booms and Busts, dicembre 2013.

8. D. Parisi, Is There Room for 'Fear' as a Human Passion in the Work by Adam Smith?, gennaio 2014

9. E. Brenna, F. Spandonaro, Does federalism induce patients' mobility across regions? Evidence from the Italian experience, febbraio 2014.

10. A. Monticini, F. Ravazzolo, Forecasting the intraday market price of money, febbraio 2014.

11. Tiziana Assenza, Jakob Grazzini, Cars Hommes, Domenico Massaro, PQ Strategies in Monopolistic Competition: Some Insights from the Lab, marzo 2014.

12. R. Davidson, A. Monticini, Heteroskedasticity-and-Autocorrelation-Consistent Bootstrapping, marzo 2014.

13. C. Lucifora, S. Moriconi, Policy Myopia and Labour Market Institutions, giugno 2014.

14. N. Pecora, A. Spelta, Shareholding Network in the Euro Area Banking Market, giugno 2014.

15. G. Mazzolini, The economic consequences of accidents at work, giugno 2014.

16. M. Ambrosanio, P. Balduzzi, M. Bordignon, Economic crisis and fiscal federalism in Italy, settembre 2014.

17. P. Bingley, L. Cappellari, K. Tatsiramos, Family, Community and Long-Term Earnings Inequality, ottobre 2014.

18. S. Frazzoni, M. L. Mancusi, Z. Rotondi, M. Sobrero, A. Vezzulli, Innovation and export in SMEs: the role of relationship banking, novembre 2014.

19. H. Gnutzmann, Price Discrimination in Asymmetric Industries: Implications for Competition and Welfare, novembre 2014.

20. A. Baglioni, A. Boitani, M. Bordignon, Labor mobility and fiscal policy in a currency union, novembre 2014.

21. C. Nielsen, Rational Overconfidence and Social Security, dicembre 2014.

22. M. Kurz, M. Motolese, G. Piccillo, H. Wu, Monetary Policy with Diverse Private Expectations, febbraio 2015.

23. S. Piccolo, P. Tedeschi, G. Ursino, How Limiting Deceptive Practices Harms Consumers, maggio 2015.

24. A.K.S. Chand, S. Currarini, G. Ursino, Cheap Talk with Correlated Signals, maggio 2015.

25. S. Piccolo, P. Tedeschi, G. Ursino, Deceptive Advertising with Rational Buyers, giugno 2015. 
26. S. Piccolo, E. Tarantino, G. Ursino, The Value of Transparency in Multidivisional Firms, giugno 2015.

27. G. Ursino, Supply Chain Control: a Theory of Vertical Integration, giugno 2015.

28. I. Aldasoro, D. Delli Gatti, E. Faia, Bank Networks: Contagion, Systemic Risk and Prudential Policy, luglio 2015.

29. S. Moriconi, G. Peri, Country-Specific Preferences and Employment Rates in Europe, settembre 2015.

30. R. Crinò, L. Ogliari, Financial Frictions, Product Quality, and International Trade, settembre 2015.

31. J. Grazzini, A. Spelta, An empirical analysis of the global input-output network and its evolution, ottobre 2015.

32. L. Cappellari, A. Di Paolo, Bilingual Schooling and Earnings: Evidence from a Languagein-Education Reform, novembre 2015.

33. A. Litina, S. Moriconi, S. Zanaj, The Cultural Transmission of Environmental Preferences: Evidence from International Migration, novembre 2015.

34. S. Moriconi, P. M. Picard, S. Zanaj, Commodity Taxation and Regulatory Competition, novembre 2015.

35. M. Bordignon, V. Grembi, S. Piazza, Who do you blame in local finance? An analysis of municipal financing in Italy, dicembre 2015.

36. A. Spelta, A unified view of systemic risk: detecting SIFIs and forecasting the financial cycle via EWSs, gennaio 2016.

37. N. Pecora, A. Spelta, Discovering SIFIs in interbank communities, febbraio 2016.

38. M. Botta, L. Colombo, Macroeconomic and Institutional Determinants of Capital Structure Decisions, aprile 2016.

39. A. Gamba, G. Immordino, S. Piccolo, Organized Crime and the Bright Side of Subversion of Law, maggio 2016.

40. L. Corno, N. Hildebrandt, A. Voena, Weather Shocks, Age of Marriage and the Direction of Marriage Payments, maggio 2016.

41. A. Spelta, Stock prices prediction via tensor decomposition and links forecast, maggio 2016.

42. T. Assenza, D. Delli Gatti, J. Grazzini, G. Ricchiuti, Heterogeneous Firms and International Trade: The role of productivity and financial fragility, giugno 2016.

43. S. Moriconi, Taxation, industry integration and production efficiency, giugno 2016.

44. L. Fiorito, C. Orsi, Survival Value and a Robust, Practical, Joyless Individualism: Thomas Nixon Carver, Social Justice, and Eugenics, luglio 2016.

45. E. Cottini, P. Ghinetti, Employment insecurity and employees' health in Denmark, settembre 2016.

46. G. Cecere, N. Corrocher, M. L. Mancusi, Financial constraints and public funding for ecoinnovation: Empirical evidence on European SMEs, settembre 2016.

47. E. Brenna, L. Gitto, Financing elderly care in Italy and Europe. Is there a common vision?, settembre 2016.

48. D. G. C. Britto, Unemployment Insurance and the Duration of Employment: Theory and Evidence from a Regression Kink Design, settembre 2016.

49. E. Caroli, C.Lucifora, D. Vigani, Is there a Retirement-Health Care utilization puzzle? Evidence from SHARE data in Europe, ottobre 2016.

50. G. Femminis, From simple growth to numerical simulations: A primer in dynamic programming, ottobre 2016.

51. C. Lucifora, M. Tonello, Monitoring and sanctioning cheating at school: What works? Evidence from a national evaluation program, ottobre 2016. 
52. A. Baglioni, M. Esposito, Modigliani-Miller Doesn't Hold in a "Bailinable” World: A New Capital Structure to Reduce the Banks' Funding Cost, novembre 2016.

53. L. Cappellari, P. Castelnovo, D. Checchi, M. Leonardi, Skilled or educated? Educational reforms, human capital and earnings, novembre 2016.

54. D. Britto, S. Fiorin, Corruption and Legislature Size: Evidence from Brazil, dicembre 2016. 